\title{
The oratory of Dwight D. Eisenhower
}

Book or Report Section

Accepted Version

Oliva, M. (2017) The oratory of Dwight D. Eisenhower. In: Crines, A. S. and Hatzisavvidou, S. (eds.) Republican orators from Eisenhower to Trump. Rhetoric, Politics and Society. Palgrave MacMillan, pp. 11-39. ISBN 9783319685441 doi: https://doi.org/10.1007/978-3-319-68545-8 Available at https://centaur.reading.ac.uk/69178/

It is advisable to refer to the publisher's version if you intend to cite from the work. See Guidance on citing.

To link to this article DOI: http://dx.doi.org/10.1007/978-3-319-68545-8

Publisher: Palgrave MacMillan

All outputs in CentAUR are protected by Intellectual Property Rights law, including copyright law. Copyright and IPR is retained by the creators or other copyright holders. Terms and conditions for use of this material are defined in the End User Agreement.

\section{www.reading.ac.uk/centaur}

\section{CentAUR}

Central Archive at the University of Reading

Reading's research outputs online 


\section{THE ORATORY OF DWIGHT D. EISENHOWER \\ Dr Mara Oliva}

Department of History

University of Reading

m.oliva@reading.ac.uk

word count: 9255 (including referencing) 
On November 4, 1952, Republican Dwight D. Eisenhower became the $34^{\text {th }}$ President of the United States with a landslide, thus ending the Democratic Party twenty years occupancy of the White House. He also carried his Party to a narrow control of both the House of Representatives and the Senate. His success, not the Party's, was repeated in 1956. Even more impressive than Eisenhower's two landslide victories was his ability to protect and maintain his popularity among the American people throughout the eight years of his presidency. When he left the White House in January 1961, his approval rating was 65 per cent (Gallup Polls, 2016). His rhetoric played an important role in preserving this popularity. Indeed, it was one of the tools he most frequently used to retain flexibility and manoeuvrability. These in turn allowed him to implement what he believed were the right policies without compromising his standing among the American people. Yet, his rhetorical and oratorical skills are still poorly understood today.

The historiography has sufficiently discredited the orthodox school of thought of the 1950s and 1960s that mocked this President for his verbal ambiguities and lacklustre style. (Barber, 1972). Eisenhower's staff accounts and revisionist historians, such as Stephen Ambrose (1984) and Fred Greenstein (1982) have clearly shown that Ike intentionally projected a friendly image and muddles grammar to divert unwanted attention to some of his policies and retain freedom to choose his options. Among the scholars of this period, the one who certainly offered the most ground-breaking assessment of Eisenhower's rhetoric is political scientist Martin Medhurst (1993). Medhurst argues that the President successfully used his rhetoric as a weapon to wage the Cold War. He used it especially during crises to effect change or 
modification in the existing situation and to influence the beliefs, attitudes and actions of both domestic and foreign audiences. In his view, Eisenhower was a master of rhetoric.

In the last twenty years, a post revisionist wave of literature has tried to strike a balance between these two extreme schools of thought. Scholars like Ira Chernus (2003) and Chris Tudda (2006) acknowledge that the President was often, not always, an effective speaker. But his rhetorical strategy, however skilfully implemented, created a paradox. As Eisenhower claimed he wanted peace, he needed to wage war "rhetorically" in order to maintain national unity and support for his foreign policy. By doing so, he exacerbated the already hostile public feelings towards the enemy, made the USSR more insecure and thus peace more difficult to achieve.

This chapter agrees with the post-revisionist school of thought. Eisenhower deserves more credit for his rhetorical skills than previously acknowledged, but on the other hand, his communication strategies were not always effective. The chapter also argues that thus far scholars have predominantly focused on the Cold War discourse. Analyses have looked at how the international context affected Eisenhower's rhetorical content and how, in turn, the President tried to influence domestic and foreign audiences through his words. But, although it is almost impossible to separate rhetorical content from how it is said, the literature still lacks an adequate understanding of Eisenhower's oratorical choices. By looking at Eisenhower's major speeches from 1945 to 1960 , this chapter aims at filling this gap. In particular, it will focus on four research questions: 
1) How did Eisenhower's oratory and rhetoric include Aristotle's primary modes of persuasive appeal: ethos, pathos and logos?

2) What did he want to achieve through his oratory and rhetoric?

3) How did he exploit the rising power of the media, especially TV?

4) What characterised his oratory and delivery?

\section{EISENHOWER'S ETHOS \& PATHOS}

Aristotle (1991) argued that an effective orator must generate credibility with their audience through their ethos by showing their personal characteristics and experience. He also believed that pathos, the ability to evoke an emotional connection with the audience, was the most powerful persuasive tool (Leith, 2011:47).

Eisenhower's ethos was already firmly established well before he entered the political arena. As Supreme Allied Commander in Europe during World War II, he became an international hero by defeating Hitler and the Nazi regime. Through the media reports of the conflict, he connected with millions of Americans who came to know the General not only as a strong military man, but also as a far-sighted and determined leader. Between 1944 and 1945, they heard his firm but compassionate voice reassuring them over the progress of the war in many radio recorded programmes. His friendly smile appeared in several newsreels produced by the US Army Pictorial Service and distributed in movie theatres across the United States. By the time he returned to the US in June 1945, Time magazine had already dedicated him four covers, including Man of the Year in January 1945. (Time, 1945). 
His triumphant return was welcomed by huge crowds and celebrations all over the United States. In Washington DC, he was invited to address a joint session of Congress. During the speech, the first of many, Eisenhower spoke extemporaneously of the courageous men and women who had fought for freedom and peace, two themes which would become a staple of his rhetoric during his political career. Declaring:

"In humble realisation that they, who earned your commendation, should properly be here to receive it, I am nevertheless proud and honoured to serve as your agent in conveying it to them." (Eisenhower, 1945).

He won his audience over by showing humility and praising soldiers, officials, allies and the American effort at home. According to a reporter covering the event, the General received a "tremendous ovation, everyone is standing up on their feet" and the largest applause for anyone who has ever addressed Congress (Eisenhower's Address to Congress, 1945).

The following day, he flew to New York where thousands of people, from LaGuardia airport to Washington Square, lined the parade route to welcome Ike. NBC reported that Eisenhower's homecoming was the most widely publicised event since Lindbergh came back from Paris. There were more than two million people outside City Hall, where he was made honorary citizen of New York City. (Eisenhower Day Ceremony, 1945). Though tired, the General never seemed to lose his famous grin. On June 22, his hometown of Abilene, Kansas, held an old fashion, non-military parade featuring scenes of the Abilene Eisenhower had known when he was a boy. One sign read: 
"Welcome to our hero!" (Kansas Historical Quarterly, 1945). But in addressing the crowd, Eisenhower declared:

"I am not a hero, I am the symbol of heroic men....it has been my great honour to command three millions Americans and women in Europe." (Eisenhower, 1945)

For the next three years and half, Eisenhower delivered more than 124 formal speeches. The public loved him and invitations poured from every corner of the country. The image that these speeches created was one of a humble man who talked more like a soldier than an officer. As he told an audience at Norwich University in Vermont, on June 9, 1946:

"I am here in the name of millions of Allied fighting men, authors of memorable victories in the Mediterranean and in Western Europe. I will never be able to express the greatness of my pride in their accomplishments. So I am unable to make them, or you, understand the depth of my humility when a great institution such as this calls me to act as their representative to receive tribute to their soldierly virtues." (Eisenhower, 1946).

He often spoke of the importance of teamwork:

"Many accomplishments in these two past years can be attributed not to anyone nation or man, but to the fact the all of us had our sights trained on a definite goal and we pulled together as a team." (Eisenhower, 1945). 
Though he had seen the horrors of war first hand, his message was one of optimism: "courage, devotion, drive, sacrifice, discipline, mutual help, loyalty" (Eisenhower, 1946) these were the values Ike projected and was associated with.

As argued by Medhurst (1993:5-16), this image was reinforced by the publication of three best-selling books. In 1945, Kenneth S. Davis wrote the first full-length biography of Eisenhower, Soldier of Democracy (1945). The book painted a picture of Eisenhower as a humble man, dedicated to service and duty and devoted to the protection of democracy. Just one year after, Harry Butcher, Eisenhower's Naval Aide from 1942 to 1945, published his memoir, My Three Years with Eisenhower (1946). In his portray, the General emerged as a man very considerate of other people's opinions and feelings but also a brave strategist and leader. Similarly, Eisenhower's own memoir, Crusade in Europe (1948), reinforced what a compassionate but also courageous and astute decision maker he was. As Ambrose (1984:237) wrote the book was greeted with "almost unanimous critical acclaim and praise for its author's modesty, candor, fairness, tact and general humanity." The following year, the book spun off into a TV series. Aired by $A B C$, it was the first documentary produced for the TV. Many of the 126 episodes featured on-camera and narrated segments that Eisenhower recorded. It received a Peabody Award and one of the first Emmy Awards for best Public Service, Cultural and Educational programme. (Allen, 1993:16; Internet Movie Database, 2016). 
In 1948, Eisenhower became the President of Columbia University and a few years later, he was appointed as the first NATO Supreme Commander. These prestigious appointments combined with his successful military records showed the American people that Ike could lead in many diverse fields, from military command to education, from administration to diplomacy (Medhurst, 1993:18). They also perfectly positioned him as the ideal candidate for the 1952 Presidential election.

Whether he wanted the job or not has been the subject of debate among historians. Regardless, it is true that both parties wanted him because both knew he could win. According to Ambrose (1982:228), in 1947 President Truman told lke that he would run as his vice-presidential nominee, if the General joined the Democratic Party. 1948 Republican candidate, Tom Dewey told Milton Eisenhower, that the General's popularity among the American people was so great that "he was a public possession." (Halberstam, 1993:209). On June 23, 1952, Ike announced he would run for President as a Republican.

After easily securing the nomination, Eisenhower fought one of the most brutal campaigns of the twenty-century. The campaign drew entirely on his ethos and his ability to connect with voters through his warm smiles, plain talk and heroic image. It was the last whistle stop campaign. He travelled forty-five states with his special train nicknamed "Look Ahead, Neighbor!". It was the first media campaign. Citizens for Eisenhower designed and paid for a series of one-minute television ads entitled "Eisenhower Answers America." In each ad, one citizen would ask the General a question either about economy, social security or the Korean War. Behind every answer lay 
Eisenhower's ethos. In brief and simple messages, he pitted his expertise, experience and character against the corrupted and incompetent policies of the Truman administration. Another ad was entitled "The Man from Abilene" and told the story of Eisenhower's humble beginnings in Kansas to his victory in Europe. In other words, it portrayed the General as the embodiment of the American Dream. The most popular ad was the "I like Ike" ad, which turned the catching phrase into part of the American political language. (The Living Room Candidate, 2016 \& Wood, 1990).

The high point of this campaign came on October 24, 1952 in Detroit, when the General announced: "I shall go to Korea!". The success of the speech hinged entirely on Eisenhower's ethos and pathos. He captured the nation's feelings by declaring:

"In this anxious autumn for America, one fact looms above all others in our people's minds. One tragedy challenges all men dedicated to the work of peace. One word shouts denial to those who foolishly pretend that ours is not a nation at war. This fact, this tragedy, this word is: Korea." (Eisenhower, 1952)

He then drew on his experience to tell the American people that if elected, what he had done during World War II could be successfully repeated (Medhurst, 2000).

"I know something of this totalitarian mind. Through the years of World War II, I carried a heavy burden of decision into the free world's crusade against tyranny then threatening us all. Month after month, year after year, 
I had to search out and weight the strengths and the weaknesses of an enemy driven by lust to rule the great globe itself." (Eisenhower, 1952)

The result was a landslide victory.

\section{EISENHOWER, SPEECHMAKING \& SPEECHWRITERS}

Preserving this image of a humble war hero dedicated to service became one of Eisenhower's priorities once he entered the White House in January 1953. Rhetoric and oratory were the two main tools he used to succeed. Eisenhower had no use for mere talks. All rhetorical flourishes made him uneasy (Hughes, 1963:25). Indeed, speeches and addresses had to be purposive. As one of his speechwriters, William Bragg Ewald Jr (1977), noted: "Eisenhower used language to accomplish his purposes, and if such purposes required indirection, suggestions, nuance generalities or intended ambiguity, that was what he would use." In other words for Eisenhower, rhetoric and oratory existed only to achieve particular goals with specific audiences. His four main goals were:

1) Maintaining his popularity among the American people

2) Protecting himself from media attacks

3) Uniting the Republican party but at the same time retaining manoeuvrability from Congress

4) Regaining the initiative in the Cold War 
Considering his role as chief of state as a symbol of national unity, Eisenhower believed that his primary responsibility lay in leading the public. As an internal memorandum reveals, "he felt his big job was selling the people of America the things that they have for the best of all the people." (Whitman, 1953). To do so, he deemed it essential not to become involved in public controversies or to be exposed to personal attacks that could damage his credibility and his popularity among the American people, which he had so carefully cultivated for the past decade. This consideration shaped his relationship with the press and Congress.

Eisenhower's Press Secretary, James C. Hagerty (1977), agreed that it was essential for Ike to protect his popularity. In order to achieve this, he suggested that the Ike "present his case to the public as often as possible" through frequent public speaking engagements and regular weekly press conferences. In particular, both men were keen on exploiting the new rising medium of television. As Eisenhower's economic adviser, Gabriel Hauge, stated in his enthusiastic response to the idea, "television is a medium that provides insight, sound, motion, immediate action and creation of great intimacy." (Hauge, 1953). By presenting his message over the head of Congress and the press, Ike could establish a direct link with the American people and gain some political leverage in the process. As a result a series of Eisenhower's reports to the nation on live television (later called TV fireside chats) was created. The news conference format was also expanded by allowing direct quotations of the President's statements. This latter decision, especially welcomed by the media, led to the radio recordings and live television coverage of the press conference (Oliva, 2017). In historian Craig 
Allen's words, "with these moves Eisenhower took a stride toward achieving a routine of placing his exact words before the public and having them stand alone against potential journalistic distortion or interpretation." (Allen, 1993: $54)$.

Eisenhower's press conferences were often subject to press mockery at the time and led in great part to the wrongful impression that the President did not have a good command of the English language. But Medhurst (1993) and Greenstein (1982:25-38), among others, have convincingly shown that Eisenhower intentionally used "jumbled syntax" and "long, inappropriate and impossibly confusing answers" to defuse controversial questions from pressing journalists. When he wanted to make his intentions clear, he delegated others like his Secretary of State John Foster Dulles or his Press Secretary James C. Hagerty, to serve as "lighting rods" for what were in reality his policies. Thanks to this "hidden-hand' leadership style, he was able to retain his credibility both domestically and internationally.

Direct appeal to the people by using the media also helped Eisenhower shield himself from Congress, especially those GOP legislators who had little experience of supporting the White House. As he explained to his Cabinet, "Congressional Republicans have been so used to a Democratic President that their instinct is to automatically oppose anything that comes from the executive branch." (Cabinet Meeting, 1953). Realising instead that a loss of one or both Houses in Congress was a strong possibility for the mid-term elections of 1954 , he decided to protect his image by presenting himself as "the President of all the people" (Donovan, 1956:271) and told his staff he would not use the Office of the Presidency to campaign for the party. 
It would be a mistake however to think that he had no interest in rebuilding the Republican Party. On the contrary, as director of USIA and Special Assistant to the President, Arthur Larson, recalled in his memoir (1968), this was one of Eisenhower's priorities throughout his eight years Presidency. The President strongly believed that the future of the party depended on the support from the youth. It was necessary to find new young candidates and new ideas to replace the conservative right-wing. He used many of his speeches to push this agenda forward. The best example is probably his 1956 Acceptance Speech. Delivered on the $100^{\text {th }}$ anniversary of the GOP convention, its message was in a nutshell: "The Republican Party is the Party of the Future". Elaborating on why this was the case, Eisenhower focused entirely on appealing to the young voters through optimism and hope.

"It is the Party which concentrates on the facts and the issues of today and tomorrow, not the facts and issues of yesterday...the Party of the Young...let us quit fighting the battles of the past, and let us turn all our attention to these problems of the present future, on which long-term well being of our people so urgently depends...The Republican Party is the Party of the Future because it draws people together, not drives them apart...the Republican Party is the Party of the Future because it is the party through which the may things that still need doing will soonest be done and will be done by enlisting the fullest energies of free, creative, individual people...." (Eisenhower, 1956).

As stated in the introduction, the literature on Eisenhower and rhetoric has already extensively covered the foreign policy and Cold War discourses 
(Medhurst, 1994b). For this reason and because of space limitation, this chapter will only look briefly at Eisenhower's fourth goal: recapturing the Cold War initiative. Eisenhower believed that the Cold War was not going to end any time soon, instead the US should be prepared for the long haul. For the President, the war was first and foremost, a battle of perceptions, beliefs and attitudes where rhetoric could be used as a very effective weapon to trigger instability and disruption in the enemy but also to persuade those non-aligned countries to join the American side. At the same time, he realised that the nuclear arms race had turned Armageddon into a reality and that as such war had become an impossible alternative. In order to sustain the US effort in the face of a prolonged war, recapture the propaganda offensive, weaken the Soviet Union and cultivate favourable domestic and international public opinion, Eisenhower turned to psychological warfare. With speeches such as a "Chance for Peace" (Eisenhower, 1953), "Atoms for Peace" (Eisenhower, 1953) and the "Open Skies" proposal (Eisenhower, 1955), he coordinated a peace offensive that presented the US as the more reasonable party, genuinely interested in working towards peace, and the Soviet Union as a relentless danger to civilisation and human progress (Schaefermeyer, 1994). Eisenhower's pragmatic and purposive approach to speech making was reflected in his speech writing system. Coordinated by the Chief of Staff, Sherman Adams, "the calendar committee" consisted of White House Appointments Secretary Thomas Stephens, Press Secretary James Hagerty, the President's personal economic advisor, Gabriel Hauge and top aides and policy makers who contributed to a particular speech according to their expertise and policy interests. For example, Secretary of State, John Foster 
Dulles, always participated in writing foreign policy addresses and messages (Adams, 1962:80).

Over the eight years of the Eisenhower presidency, they were supported by five head speechwriters. Emmet Hughes, a loan from Life/Time magazines with a background in foreign policy, unlike the President, he revelled in playing with rhetorical devices and idealistic language. Not surprisingly, he coauthored some of Eisenhower's most eloquent speeches, such as the two Inaugurals and a Chance for Peace. He was succeeded by Bryce Harlow in late 1953 who like the President was more pragmatic in his approach to speechwriting. Kevin McCann came on board in January 1955 . He was a personal friend of Eisenhower and more than any other speechwriters he understood the President's personality and ideas. He was replaced by Arthur Larson in October 1957. Larson shared Hagerty's belief that the "President was the most effective single educational medium in the country" and therefore his image had to be protected and his message spread as of often as possible (Larson,1968:159-178). He was very active in expanding the role of TV in the White House communication system. Malcolm Moos, professor of political science at Johns Hopkins University, became the head speechwriter in the autumn of 1958. Eisenhower found him the easiest speechwriter to work with because he never tried to impose his views on speech content or form. Moos felt his job was simply to put on paper the President's thoughts. In his words: 'I try to find out what the President wants to say and help him to say in the best way." (Griffin, 2003:76-78).

Eisenhower valued the benefits of teamwork and having a systemised speechwriting operation guaranteed quality results, but he also made sure 
everybody knew that ultimately he would not give a speech unless he, the President, was 100 per cent satisfied with the script. Whether these were routine speeches or important occasions, Ike was always involved in the writing process. In the case of the former, he did not mind having his staff working on a draft first and then edit their work. But for important speeches, he would initiate the process himself by instructing Adams to gather the relevant information and staff and begin working on a specific issue for a specific audience. (Walcott, \& Hult, 1994).

All Eisenhower's aides agree that regardless of the timing of the President's involvement, when he entered the process, he was quite an aggressive editor and would work on the speech right up to its delivery. Speechwriter, William Bragg Ewald Jr (1977) noted that his former "boss had been intimately involved in drafting speeches and often rewrote them just before delivering them." He was a very meticular editor. Larson corroborated this by writing "He worked and revised his manuscripts endlessly. No speech manuscript was finished until he arrived to the podium." (Larson, 1968:160). And Emmet Hughes (1963:17-18) recalled in his memoir, that his criticism could range from "details of substance to points of style and quality of grammar."

When discussing or editing a speech, Eisenhower always followed the same criteria. First of all, a speech should only be given if necessary and with an objective. Addresses should preferably be short to maximise the effectiveness of the message. Rhetorical embellishments should be avoided, instead words should be simple and clear to make the speech accessible to as many people as possible. Generalizations too should be avoided and any assertion must be 
accurate. Finally, and most important, the speech had to convey a level of dignity appropriate to the Oval Office. (Larson, 1968 \& Griffin, 2003).

It is often questioned whether a speech should be attributed to the orator or the person who actually writes the speech. Through this systemised speech writing process and aggressive editing, Eisenhower made the speeches his own. The final product always reflected the President's ideas and views.

\section{EISENHOWER'S LOGOS}

Aristotle (1991) described logos as an appeal to reason through the identification of the issues at the heart of the debate and "the structure of thought these arguments compose." (Cockcroft \& Cockcroft, 2014:7-8). Eisenhower's choice of themes, structure and language for his speeches further reinforces the argument that the President had a competent and pragmatic understanding of the use of oratory and rhetoric. He identified key issues and manipulated them through various oratorical devices to appeal to different audiences.

\section{Themes}

Eisenhower chose three main themes to convey his message and policies to the American people and the world: freedom, peace and strength. These were present in all of his major speeches and public addresses throughout the eight years of his presidency. All three were broad enough to be easily adapted according to the goal of the message and the target audience.

"The future shall belong to the free" so the new President proclaimed in his first Inaugural Address in 1953. His statement reflected his profound belief in 
the superiority of the American way of life. Only through a free government, free market and freedom of belief and worship could a democracy thrive and humanity progress. The American people had to fight, and at time sacrifice, to preserve these liberties. Eisenhower was especially afraid that the people would soon get tired of fighting a long war against the Soviet Union, particularly if this involved excessive government spending and high taxation. Communism and fiscal instability could eventually lead to war. Public Opinion needed to understand what was at stake in order to support the government's policies. To foreign audiences, especially those non-aligned third world countries, freedom, the American way, represented something to aspire to break away from slavery and old colonial rule.

For Eisenhower, freedom and peace were indivisible. He spoke of the "golden age of freedom and peace" (Chance for Peace, 1953) and of peace "being the climate of freedom" (Inaugural 1957). Peace meant first and foremost preventing nuclear war. As he declared in his Atoms for Peace Address in 1953, "the atomic armaments race which overshadows not only the peace, but the very life, of the world," he understood that in an atomic age total war as instrument of policy was unthinkable.

Freedom and peace could be achieved through strength. Military, economic and spiritual strength will unite and protect the country and deter enemies:

"Knowing that only a United States that is strong and immensely productive can help defend freedom in our world, we view our Nation's strength and security as a trust upon which rests the hope of the free men everywhere." (Eisenhower, 1953). 
These themes were linked together by a religious thread that ran through all speeches. Eisenhower was not a religious man. As he confessed to a newly famous Billy Graham who was visiting him in Paris in 1951, he had never been baptised and he and his wife Mamie rarely attended church. But he consciously became the figurehead of the 1950s religious revival. His eight years presidency was unprecedented in American history for its introduction of religious language and symbols into political life (Gunn \& Slighoua, 2011). Indeed, he began his presidency with a "little private prayer" which he read to millions of people listening at the Capitol and watching from home on TV. A week after, he was baptised into the Presbyterian Church. He instituted the White House Prayer Breakfast (now the National Prayer Breakfast), advocated the addition of the words "under God" to the pledge of allegiance and helped to raise "In God We Trust" to its status as the nation's official motto. He was not interested in where faith came from or how it worked, but he strongly believed it was necessary for the survival of democracy. It was only through religious faith that human beings could self-restrain and get along thus preventing society from turning into chaos (Holloway, 1994).

\section{Structure}

When addressing the American people or delivering a speech aimed at rallying domestic and international support for US policies or at enhancing American image abroad and beyond the Iron Curtain, Eisenhower often used the Monroe's Motivated Sequence to structure his speeches. This technique for organising persuasive speeches that inspire people to take action was developed in the 1930 s by political scientist Alan H. Monroe. The advantage 
of it is that it creates an emotional link between the speaker and the audience by showing that the speaker understands the problem at hand and cares about solving it, and by making the audience involved as part of the solution by emphasising a call to action. It consists of five steps: 1) attention; 2) problem; 3) solution; 4) visualisation; 5) action (German, K., M., Gronbeck, B. E., Ehninger, D., Monroe, A. H. 2010).

The best example of Eisenhower's use of the Monroe Motivated Sequence is the Atoms for Peace speech. Delivered on 8 December, 1953 to the United Nations General Assembly, the speech, as Medhurst (1997) has argued, had several objectives. It was first of all a psychological warfare effort aimed at portraying the US as a peaceful nation willing to share its technological knowledge with the rest of the world and the Soviet Union as dangerously obsessed with nuclear war. It was also meant to contribute to the implementation of the administration's New Look doctrine by diverting public attention from the on-going nuclear arms race and gaining access to foreign markets and raw material in exchange for US atomic energy assistance. The speech rhetorical strategy covered all three goals.

Eisenhower's opening line immediately grabbed the audience attention by stressing the significance of the occasion:

"Never before in history has so much hope for so many people been gathered together into a single organisation" 
He then clearly stated the problem at hands: atomic weapons had changed the nature of warfare and the Soviet Union had accumulated an increasingly dangerous number of them.

\begin{abstract}
"The new language is the language of atomic warfare.....atomic bombs today are more than 25 times as powerful as the weapons with which the atomic age dawned, and hydrogen weapons are in ranges of millions of tons of TNT equivalent. The Soviet Union has informed us that, over recent years, it has devoted extensive resources to atomic weapons."
\end{abstract}

After successfully presenting Moscow as a threat to humanity, he offered the solution:

\footnotetext{
"The United States, heeding the suggestion of the General Assembly of the United Nations, is instantly prepared to meet privately with such other countries as may be principally involved to seek an acceptable solution to the atomic armaments race which overshadows not only the peace, but the very life, of the world."
}

He elaborated on the proposed solution by reinforcing America's image as a peace loving nation which could lead the world to a safe future and a safe use of atomic energy.

\footnotetext{
"Occasional pages of history do record the faces of the "Great Destroyers" but the whole book of history reveals mankind's never-ending quest for peace and mankind's God-given capacity to build. It is the book of history,
} 
and not the isolated pages, that he United States will ever wish to be identified. My country wants to be constructive, not destructive. It wants agreements, not wars, among nations. It wants itself to live in freedom and in the confidence that the people of every other nation enjoy equally the right of choosing their own way of life. So my country's purpose is to help us move out of the dark chamber of horrors into the light, to find a way by which the minds of men, the hopes of men, the souls of men everywhere, can move forward toward peace and happiness and well being."

He concluded by invoking everybody's help. The success of the plan/visualisation did not depend on the US only. But all nations, countries and citizens were called to play a role in the progress towards peace.

\footnotetext{
"Against the dark background of the atomic bomb, the United States does not wish merely to present strength, but also the desire and the hope for peace. The coming months will be fraught with fateful decisions. In this Assembly; in the capitals and military headquarters; in the hearts of men every where, be they governors or governed, may the be the decisions which will lead this world out of the fear and into peace."
}

For the State of the Union Annual Message, Eisenhower abandoned the full Monroe's Motivated Sequence and instead focused on steps two and three only: problem and solution. The President saw this message not as a general address that should be accessible in order to persuade as many people as possible. Rather, he reverted to his military background. The General (now 
President) was telling his staff (now Congress) what needed to be done and how it needed to be done. For example, in the 1954 State of the Union, he identified the Communist threat as the main problem to American security:

\begin{abstract}
"American freedom is threatened so long as the world Communist conspiracy exists in its present scope, power and hostility." (Eisenhower, 1954).
\end{abstract}

He then offered the solution:

\begin{abstract}
"Our military power continues to grow. This power is for our own defence and to deter aggression. We shall not be aggressors, but we and our allies have and will maintain a massive capability to strike back." (Eisenhower, 1954)
\end{abstract}

He elaborated on the solution by presenting a "list of things to do", i.e. what Congress should do to solve the problem.

"At the foundation of our economic growth are the raw materials and energy produced from our materials and fuels, lands, forests, and water resources. With respect to them, I believe the nation must adhere to three fundamental policies: first, to develop, wisely use and conserve basic resources from generation to generation; second, to follow the historic pattern of developing these resources primarily by private citizens by fair provisions of law, including restraints for proper conservation; and third, to treat resource development as a partnership undertaking - a partnership in which the participation of private citizens 
and State and local governments is as necessary as Federal participation." (Eisenhower, 1954)

Listing the necessary steps to solve the problems was a typical feature of Eisenhower's State of the Union messages. During the eight years of the Presidency, every message contained at least 2 or 3 "lists." These made the speeches quite lengthy and content dense, thus less accessible to the general public. The only exception was the State of the Union of 1958. The speech came just a few months after the launch of Sputnik. Eisenhower abandoned the problem/solution/list structure for the first half of the speech. Instead, he reverted to the Monroe Motivated Sequence to reassure the American people that the missile gap did not exist and that America was ready to face any forms of threat or danger. The second half of the speech went back to the problem/solution structure including a 2-page long list of eight actions for Congress.

\section{Language}

The differentiation between audiences was also clear from the language used. Counting words, paragraphs, words per sentence and characters per word offers some insight into the complexity of Eisenhower's rhetoric. The Flesch Reading Ease Index (FREI), a scale of 100 where the higher score, the easier to understand and the Flesch Kincaid Grade Level Test (FKGL), which rates comprehension in terms of US schools grades (so a score of 8.0 means an eight grader can understand the speech), can be used to indicate the level at which Eisenhower's rhetoric was pitched so indicating its complexity. Table 1 
clearly shows there is a striking distinction between his campaign and wider audience speeches and the State of the Union Messages.

\begin{tabular}{|c|c|c|c|c|c|c|c|c|c|c|}
\hline Speech & $\begin{array}{l}\mathrm{N} \text { of } \\
\text { paras }\end{array}$ & $\begin{array}{l}\text { Words per } \\
\text { sentence } \\
1 / 10\end{array}$ & $10 / 20$ & $20 / 30$ & $30 / 40$ & $40+$ & $\begin{array}{l}\text { Average } \\
\text { Word } \\
\text { number per } \\
\text { sentence }\end{array}$ & $\begin{array}{l}\text { Average } \\
\text { number of } \\
\text { character } \\
\text { per word }\end{array}$ & $\begin{array}{l}\text { Flesch } \\
\text { Reading } \\
\text { Easy }\end{array}$ & $\begin{array}{l}\text { Flesch- } \\
\text { Klaid }\end{array}$ \\
\hline $\begin{array}{l}\text { I shall go to } \\
\text { Korea }\end{array}$ & 57 & 50 & 61 & 31 & 9 & 3 & 15 & 4.4 & 66 & 8 \\
\hline $\begin{array}{l}\text { Convention } \\
52\end{array}$ & 20 & 8 & 18 & 8 & 5 & 7 & 15 & 4.5 & 66 & 10 \\
\hline $\begin{array}{l}\text { Convention } \\
56\end{array}$ & 91 & 29 & 45 & 60 & 26 & 20 & 19 & 4.3 & 66 & 9 \\
\hline Inaugural ‘53 & 47 & 18 & 44 & 32 & 19 & 10 & 16 & 4.3 & 74.9 & 7 \\
\hline $\begin{array}{l}\text { Chance for } \\
\text { Peace }\end{array}$ & 104 & 19 & 64 & 44 & 13 & 4 & 16 & 4.4 & 73.3 & 7 \\
\hline $\begin{array}{l}\text { Atoms for } \\
\text { Peace }\end{array}$ & 75 & 7 & 36 & 36 & 18 & 18 & 21 & 4.6 & 60.0 & 10 \\
\hline Farewell & 33 & 12 & 27 & 21 & 8 & 8 & 25 & 5.2 & $35.9^{1}$ & 14.6 \\
\hline Inaugural ‘57 & 37 & 17 & 40 & 26 & 7 & 0 & 17 & 4.3 & 76.8 & 6.7 \\
\hline $\begin{array}{l}\text { State of the } \\
\text { Union ' } 53\end{array}$ & 147 & 29 & 141 & 109 & 40 & 17 & 21 & 5.4 & 38 & 13.3 \\
\hline $\begin{array}{l}\text { State of the } \\
\text { Union' } 54\end{array}$ & 101 & 23 & 111 & 96 & 30 & 15 & 21 & 5.2 & 40.2 & 12.8 \\
\hline $\begin{array}{l}\text { State of the } \\
\text { Union' } 55\end{array}$ & 105 & 28 & 134 & 105 & 40 & 21 & 20 & 5.2 & 39.2 & 12.8 \\
\hline $\begin{array}{l}\text { State of the } \\
\text { Union ' } 56\end{array}$ & 117 & 49 & 128 & 119 & 58 & 20 & 20 & 5 & 45.7 & 12 \\
\hline $\begin{array}{l}\text { State of the } \\
\text { Union ' } 57\end{array}$ & 64 & 22 & 65 & 55 & 26 & 14 & 23 & 5.1 & 40.1 & 13.5 \\
\hline $\begin{array}{l}\text { State of the } \\
\text { Union' } 58\end{array}$ & 121 & 35 & 81 & 80 & 33 & 7 & $19 / 24$ & $4.1 / 5.3$ & $60.3 / 43.5$ & $10 / 12$ \\
\hline $\begin{array}{l}\text { State of the } \\
\text { Union' } 59\end{array}$ & 102 & 43 & 106 & 81 & 22 & 7 & 17 & 5.3 & 44.2 & 11.3 \\
\hline $\begin{array}{l}\text { State of the } \\
\text { Union ' } 60\end{array}$ & 101 & 17 & 75 & 93 & 36 & 16 & 21 & 4.9 & 48 & 11.7 \\
\hline
\end{tabular}

Table 1 The sample is not exhaustive, but it is meant to represent the complexity of Eisenhower's oratory.

For speeches whose primary target was the general public the majority of sentences has less than 20 words and the average number of characters per word is 4.4, thus indicating simpler sentences and simpler messages. The Flesch Reading Ease Index and the Flesch-Kincaid Grade Level Test confirm that these were quite accessible speeches to all, with the Inaugural of 1957 being the easiest $(76.8-6.7)$. 
The exception is the Farewell Address. Eisenhower saw this speech as a unique rhetorical opportunity. In 1961, he was still an immensely popular figure and correctly realised that any thoughts he might express in his final message could have a deep impact on US political thinking. The speech had therefore several aims: 1) by voicing his concerns about the threat of the increasingly powerful defence establishment, he was fighting to keep a balance he thought was essential for proper government (Griffin, 1992); 2) He also wanted to strike a blow against those political enemies who had exploited the missile gap issue and against president-elect John F. Kennedy and his economic proposals; 3) finally, he wanted to give a remarkable farewell, like his hero, George Washington, to cement his historical legacy and ethos as a man of peace and above politics (Griffin, 1992 and Medhurst, 1994b). Such ambitious goals resulted in a sophisticated but less accessible speech. The average word number per sentence is 25 , the average number of characters per word is 5.2., and the Flesch Ease Reading index and Flesch Kincaid Grade Level Test are respectively 35.9 and 14.6, thus making this the most difficult speech to understand among the sample analysed.

On average sentences in the State of the Union Messages are longer, above 20 words, the number of characters per word is higher 5.1 and the Flesch Reading Index and the Flesch Kincaid Grade Level test show these were less accessible and more difficult to understand. The Flesch Reading Index has dropped from an average 73 to 39.2 for the State of the Union of 1955 and Flesch Kincaid has increased from an average 7 to 12.8 for the State of the Union of 1954. The exception is again the State of the Union of 1958. As already mentioned, the speech was delivered a few months afterward Sputnik 
so the initial part of the speech is meant to reassure US citizens and goes back to less than 20 words per sentence and 4.1 characters per word with the Flesch Reading Index at 60.3 and the Flesch Kincaid at 10. The second half of the message was for Congress, so the number of words per sentence is back up to 24, the number of characters per word is 5.3 and the FREI and FKGLT are respectively 43.5 and 12.

The differentiation among audiences was also clear from the choice of rhetorical devices. Despite his distaste for oratorical props, when he wanted to ensure his speech resonated with his audience, he turned to repetitions and metaphors.

\begin{tabular}{|c|c|c|c|c|c|c|c|c|c|}
\hline Speech & Metaphors & Alliteration & Anaphora & Antimetabole & Hypophora & Epinaphora & Epistrophe & Parachesis & Parallelism \\
\hline $\begin{array}{l}\text { I Shall go to } \\
\text { Korea }\end{array}$ & 14 & 4 & 12 & 2 & 1 & 8 & 1 & 9 & 12 \\
\hline $\begin{array}{l}\text { Convention } \\
52\end{array}$ & 12 & 6 & 5 & 5 & 0 & 3 & 5 & 1 & 9 \\
\hline $\begin{array}{l}\text { Convention } \\
56\end{array}$ & 14 & 16 & 16 & 10 & 0 & 18 & 4 & 10 & 16 \\
\hline Inaugural ‘53 & 24 & 19 & 19 & 3 & 1 & 11 & 1 & 7 & 22 \\
\hline $\begin{array}{l}\text { Chance for } \\
\text { Peace }\end{array}$ & 14 & 24 & 20 & 1 & 2 & 11 & 12 & 7 & 23 \\
\hline $\begin{array}{l}\text { Atoms for } \\
\text { Peace }\end{array}$ & 10 & 13 & 9 & 4 & 1 & 7 & 1 & 6 & 10 \\
\hline Farewell & 7 & 16 & 2 & 0 & 0 & 3 & 1 & 2 & 2 \\
\hline Inaugural ‘57 & 24 & 17 & 14 & 2 & 0 & 4 & 2 & 2 & 11 \\
\hline $\begin{array}{l}\text { State of the } \\
\text { Union' } 53\end{array}$ & 2 & 2 & 6 & 0 & 0 & 1 & 0 & 1 & 3 \\
\hline $\begin{array}{l}\text { State of the } \\
\text { Union ' } 54\end{array}$ & 1 & 2 & 2 & 0 & 0 & 1 & 0 & 1 & 1 \\
\hline $\begin{array}{l}\text { State of the } \\
\text { Union ' } 55\end{array}$ & 1 & 3 & 12 & 0 & 0 & 2 & 1 & 1 & 3 \\
\hline $\begin{array}{l}\text { State of the } \\
\text { Union '56 }\end{array}$ & 1 & 2 & 8 & 1 & 0 & 2 & 1 & 2 & 3 \\
\hline $\begin{array}{l}\text { State of the } \\
\text { Union ' } 57\end{array}$ & 4 & 8 & 5 & 0 & 0 & 3 & 1 & 2 & 5 \\
\hline $\begin{array}{l}\text { State of the } \\
\text { Union ' } 58\end{array}$ & 7 & 8 & 9 & 1 & 1 & 5 & 4 & 5 & 6 \\
\hline $\begin{array}{l}\text { State of the } \\
\text { Union '59 }\end{array}$ & 3 & 2 & 6 & 0 & 1 & 2 & 0 & 3 & 2 \\
\hline $\begin{array}{l}\text { State of the } \\
\text { Union ' } 60\end{array}$ & 2 & 4 & 1 & 0 & 0 & 2 & 0 & 2 & 2 \\
\hline
\end{tabular}

Table 2 Sample is not exhaustive but it is meant to show Eisenhower's wide range of rhetorical devices. 
Table 2 shows a clear distinction in the use of rhetorical features between campaign speeches and addresses aimed at a wider audience and the annual messages to Congress. The exception being once again the Farewell Address. Eisenhower used no less than seven types of repetitions: alliteration, anaphora, antimetabole, epinaphora, epistrophe, parachises and parallelism. He used them to communicate a sense of conviction. As Chaeteris-Black argues "the more convinced a politician sounds about his or her own ideas and beliefs, the more convincing he or she is likely to be." (2005:9-10). By repeating certain words, sounds and sentence structures, he not only supported his argument (logos), but also aroused emotions (pathos) and reinforced his reputation and credibility (ethos) as a honest supporter of democracy. The extract below from a Chance for Peace (1953) best illustrates the President's use of these rhetorical devices.

We are ready, in short, to dedicate our strength to serving the needs, rather than the fears, of the world.

We are ready, by these and all such actions, to make of the United Nations an institution that can effectively guard the peace and security of all peoples.

I know of nothing I can add to make plainer the sincere purpose of the United States.

I know of no course, other than that marked by these and similar actions, that can be called the highway of peace.

I know of only one question upon which progress waits. It is this:

What is the Soviet Union ready to do?

Whatever the answer be, let it be plainly spoken. 
Again we say: the hunger for peace is too great, the hour in history too late, for any government to mock men's hopes with mere words and promises and gestures.

The test of truth is simple. There can be no persuasion but by deeds. Is the new leadership of the Soviet Union prepared to use its decisive influence in the Communist world, including control of the flow of arms, to bring not merely an expedient truce in Korea but genuine peace in Asia?

Is it prepared to allow other nations, including those of Eastern Europe, the free choice of their own forms of government? Is it prepared to act in concert with others upon serious disarmament proposals to be made firmly effective by stringent U.N. control and inspection?

If not, where then is the concrete evidence of the Soviet Union's concern for peace?

By repeating "We are ready" (anaphora), he tapped on Americans' feelings of patriotism and unity in supporting the cause for peace. But he also presented himself as "one of them" as in we are all in this together and we need to work together to succeed in protecting peace. He then used his ethos to challenge the Soviet Union by repeating "I know of." Eisenhower, a man of peace, had tried everything possible to advance the cause of peace, now it was up to Moscow to show if it could live up to international moral standards. This implied that if peace was not achieved than it was Russia's fault. He concluded the passage with a series of rhetorical questions (hypophora) to reinforce the massage and put the Soviet Union on the spot. 
The passage is enriched by the use of metaphors. Eisenhower used metaphors mainly to simplify complicated political ideas. This is why he used them mostly in speeches aimed at wider audiences. By explaining abstract political issues through image based metaphors, he made them more intelligible and accessible. Using shared mental representations also contributed to the impression that he was telling the right story (Van Dijk, 1995) and therefore established him as a legitimate source of authority by "sounding right" (Chilton, 2004, p.47). Finally, metaphors allowed him to reach multiple audiences at the same times. Since metaphors are not precise the listener can give their own interpretation to it.

Eisenhower used a wide range of metaphors. He used single-word metaphors such as the "the price of Liberty" or "the hunger for peace" (Chance for Peace, 1953). He often used simile to put effort on context, "In the final place a soldier's pack is not so heavy as a burden on a prisoner's chains" (Inaugural, 1953). He also drew up extended images as when discussing the events in Hungary during his 1957 Inaugural Address:

"Through the night of their bondage, the unconquerable will of heroes has struck with the swift, sharp thrust of lighting. Budapest is no longer merely the name of a city; henceforth it is a new and shining symbol of men's yearning to be free."

His metaphors/images most of all featured the idea of light against darkness, such as:

"freedom is pitted against slavery, lightness against the dark" 
(Inaugural, 1953)

or

"so my country's purpose is to help us move out of the dark chambers of horror into the light"

(Atoms for Peace, 1953)

\section{Poetry, Wit \& Anecdotes}

Eisenhower rarely used poetry in his speeches and he certainly never used wit. On occasions, he would use anecdotes. For example, in the introduction of Atoms for Peace, he recalled the Bermuda meeting. He also occasionally used references to US history and quotes from past presidents he admired. For example, in the State of the Union of 1957, he declared "In the main, today's expressions of nationalism are, in spirit, echoes of our forefathers's struggle for independence" when referring to the tide of nationalism sweeping the world in 1956. And in the State of the Union of 1958, he quoted President McKinley in order to rally support for the US role in the word, "As President McKinley said, as long ago as 1901: Isolationism is no longer possible or desirable....the period of exclusiveness is past."

\section{DELIVERY}

Reading Eisenhower's speeches and listening or watching him delivering them are two very different experiences. Unfortunately, there are not many audio and video recordings left compared to other figures examined in this volume. But Eisenhower was not a natural orator and the delivery did not reflect the sophistication of the rhetorical strategy. Many of the rhetorical devices and their effectiveness were lost once the words were pronounced. Eisenhower 
read from a script and this constrained him. Since he had to focus on the written words, he would often lose that warm smile that characterised his public image. He was at his best as an orator when he could talk extemporaneously. Following a script made him often stutter thus breaking the natural flow of the speech. The other problem in reading from a script was that he had to wear glasses which in the early years of his administration were black rimmed and casted a shadow over his blue eyes making it more difficult to make eye contact with the audience.

Eisenhower was aware of this. In an attempt to improve his delivery skills, he hired Hollywood actor Robert Montgomery who immediately replaced the black glasses with a shell-rim pair. He also tried to coach Eisenhower in using a teleprompter thus abandoning the written text. These changes combined with a full revamp of the President's wardrobe slightly improved the end result but unfortunately still failed in taking full advantage of lke's oratorical potential. (Allen, 1994).

\section{CONCLUSION}

Eisenhower was a better speechwriter than orator. This does not mean however that his message was not effective or persuasive. On the contrary, if one looks at Eisenhower's rhetoric and oratory through the lenses of Aristotle's classic definition (1991), the lke comes out as a very successful communicator. Aristotle argued that effective rhetoric did not depend on the style of oratorical choices used by the speaker. Rather rhetoric as an art focused on planning, organisation, selection and purpose. Examining Eisenhower's speeches clearly shows that this definition shaped every aspect 
of the President's rhetorical strategy. This strategy was one of the most important elements of his leadership style.

As he often declared in his speeches, for lke, leading meant leading by example. Through a skilful use of ethos, pathos and logos, he was able to project a dual image of himself as an exceptional leader and as a man of the people, thus inspiring his fellow Americans to support him, his vision and his policies. To judge him on the basis of his often stuttering and script constrained delivery would only offer a partial and untrue understanding of the man. 


\section{Bibliography}

\section{Primary Sources}

\section{Speeches}

EISENHOWER, D. "Address to a joint session of Congress", 18 June, 1945

EISENHOWER, D. "Address in Abilene”, 22 June, 1945

EISENHOWER, D. "Remarks at Closing of the Allied Expeditionary Force", 28 July, 1945

EISENHOWER, D. "Speech at the American University", 10 February, 1946

EISENHOWER, D. "Address at Norwich University, Northfield, Vermont", 9 June, 1946

EISENHOWER, D. "I Shall go to Korea", 24 October, 1952

EISENHOWER, D. "Republican National Convention Acceptance Speech", 11 July, 1952

EISENHOWER, D. "Inaugural Address", 20 January, 1953

EISENHOWER, D. "Annual Message to Congress on the State of the Union", 2 February, 1953

EISENHOWER, D. "Chance for Peace”, 16 April, 1953

EISENHOWER, D. “Atoms for Peace”, 8 December, 1953

EISENHOWER, D. "Republican National Convention Acceptance Speech", 23 August, 1956

EISENHOWER, D. "Annual Message to Congress on the State of the Union", 4 January, 1954

EISENHOWER, D. "Annual Message to Congress on the State of the Union", 6 January, 1955

EISENHOWER, D. "Annual Message to Congress on the State of the Union", 
5 January, 1956

EISENHOWER, D. "Inaugural Address”, 21 January, 1957

EISENHOWER, D. "Annual Message to Congress on the State of the Union", 10 January, 1957

EISENHOWER, D. "Annual Message to Congress on the State of the Union", 9 January, 1958

EISENHOWER, D. "Annual Message to Congress on the State of the Union", 9 January, 1959

EISENHOWER, D. "Annual Message to Congress on the State of the Union", 7 January, 1960

EISENHOWER, D. "Farewell Address", 17 January, 1961

\section{Dwight D. Eisenhower Presidential Library Collections}

CABINET MEETING (1953) Eisenhower's papers, Cabinet series, box 1, Kansas, US.

HAUGE, G. (1953) Box 415, EOF, Eisenhower's papers, Kansas, US.

WHITMAN, A. (1953) Notes, ACW Diary, Box 1, Ann Whitman Diary Series, Eisenhower's papers, Kansas, US.

\section{Memoirs and Diaries}

ADAMS, S. (1962) First-Hand Report, the Story of the Eisenhower Administration, New York: Hutchingson.

BUTCHER, H. (1946) My Three Years with Eisenhower, New York: Simon \& Schuster. 
DONOVAN, R. (1956) Eisenhower: the Inside Story, New York: Harper and Brothers.

EISENHOWER, D. (1948) Crusade in Europe, New York: Doubleday.

HUGHES, E. (1963) The Ordeal of Power, A Political Memoir of the Eisenhower Years, New York: Antheneum.

LARSON, A. (1968) Eisenhower: the President Nobody Knew, London: Leslie Frewin.

\section{Oral Histories}

EWALD, B.W. (1977), Eisenhower Oral History Project, Columbia University, Butler Library, New York.

HAGERTY, J. (1977), Eisenhower Oral History Project, Columbia University, Butler Library, New York.

\section{Radio Recordings}

Eisenhower's Address to Congress, (1945), NBC, [Online] 18 June. Available at: $\quad$ http://pastdaily.com/2013/06/18/gen-eisenhower-address-to-congressjune-18-1945/ [Accessed: 13 October 2016]

\section{Video Recordings}

Eisenhower Day Ceremonies, (1945) WNYC. [Online] 19 June. Available at: http://www.wnyc.org/story/eisenhower-day-ceremonies/ [Accessed: 13 October 2016]

Eisenhower's Inaugural Address, (1953) C-SPAN [online] 20 January. Available at https://www.c-span.org/video/?5795-1/president-eisenhower1953-inaugural-address [accessed 20 November 2016]

Eisenhower's Inaugural Address, (1957) C-SPAN [online] 21 January. Available at https://www.c-span.org/video/?5795-1/president-eisenhower1953-inaugural-address [accessed 20 November 2016] 
Eisenhower's Farewell Address, (1961) Available at https://www.cspan.org/video/?15026-1/eisenhower-farewell-address [accessed 13 November, 2016]

\section{Newspapers and Magazines}

TIME (1945) Man of the Year [online] available http://time.com/archive/ [Accessed: 13 October 2016]

\section{Websites}

GALLUP POLLS. (2016) Gallup Historical statistics and trends - Presidential Approval Ratings. [Online] Available from: Gallup.com [accessed $13^{\text {th }}$ November, 2016]

KANSAS HISTORICAL SOCIETY (1945) General Eisenhower of Kansas, [Online] Available from: https://www.kshs.org/p/kansas-historical-quarterlygeneral-eisenhower-of-kansas/13002 [accessed 15th November, 2016] INTERNET MOVIE DATABASE (2016) Crusade in Europe, [Online] Available from: ImbD.com [accessed $22^{\text {nd }}$ October, 2016]

THE LIVING ROOM CANDIDATE (1952) Presidential Campaign Commercials [Online] Available from: http://www.livingroomcandidate.org [accessed $13^{\text {th }}$ September, 2016] 


\section{Secondary Sources}

\section{Articles}

GRIFFIN, C.T.G. (1992) New Light on Eisenhower's Farewell Address. Presidential Studies Quarterly. 22 (3). P. 469-479.

GUNN, T.J. \& SLIGHOUA, M. (2011) The Spiritual Factor: Eisenhower, Religion and Foreign Policy. The Review of Faith and International Affairs. 9 (4). P. 39-49.

MEDHURST, M. (1994) Reconceptualising Rhetorical History: Eisenhower's Farewell Address. Quarterly Journal of Speech. 80 (2). P. 195-218.

MEDHURST, M. (1997) Atoms for Peace and Nuclear Hegemony: The Rhetorical Structure of a Cold War Campaign. Armed Forced \& Society. 23 (4). P. 571-593.

OLIVA, M. (2017) Beaten at the Their Game: Eisenhower, Dulles, American Public Opinion and the People's Republic of China. Journal of Cold War Studies (forthcoming).

WALCOTT, C. \& HULT, K. (1994) White House Organisation as a Problem of Governance: The Eisenhower System. Presidential Studies Quarterly. 24 (2). P. 327-339.

MEDHURST, M. (2000) Text and Context in the 1952 Presidential Campaign: Eisenhower's “I Shall Go to Korea” Speech. Presidential Studies Quarterly. 30 (3). P. 464-484.

WOOD, S.C. (1990) Television's First Political Spot Ad Campaign: Eisenhower Answers America. Presidential Studies Quarterly. 20 (2). P. 265283.

\section{Books}


ARISTOTLE (1991) The Art of Rhetoric, London: Penguin Books.

ALLEN, C. (1993) Eisenhower and the Mass Media, Peace, Prosperity and

Prime-Time TV, Chapel Hill: The University of North Carolina Press.

AMBROSE, S. (1984) Eisenhower, Soldier and President, New York: Simon \& Schuster.

BARBER, J. (1972) The Presidential Character: Predicting Performance in the White House, Englewood Cliffs: Prentice Hall.

CHARTERIS-BLACK, J. (2005) Politicians and Rhetoric, The Persuasive Power of Metaphor, Basingstoke: Palgrave MacMillan.

CHERNUS, I. (2003) Eisenhower's Atom for Peace, College Station: Texas A\&M University Press.

CHILTON, P. (2004) Analysing Political Discourse, London: Routledge.

COCKCROFT, R. \& COCKCROFT, S. (2014) Persuading People: An Introduction to Rhetoric, Basingstoke, Palgrave MacMillan.

DAVIS, K. (1945) Soldier of Democracy, New York: Doubleday.

GeRMAN, K., M., GRONBECK, B. E., EHNINGER, D., MONROE, A. H. (2010). Principles of Public Speaking (17th ed.). Old Tappan, NJ: Pearson.

GREENSTEIN, F. (1982) The Hidden-Hand Presidency: Eisenhower as a Leader, New York: Basic Books.

HALBERSTAM, D. (1993) The Fifties, New York: The Random House Publishing Group.

KENNETH, S.D. (1945), Soldier of Democracy, New York: Doubleday \& Co.

LEITH, S. (2011) "You Talking to Me?" Rhetoric from Aristotle to Obama, London: Profile Books. 
MEDHURST, M. (1993) Dwight D. Eisenhower: Strategic Communicator, Westport: Greenwood Press.

MEDHURST, M. (1994) Eisenhower's War of Words: Rhetoric and Leadership, East Lansing: Michigan State University Press.

RITTER, K. \& MEDHURST, M. (eds.) (2002) Presidential Speechwriting, from the New Deal to the Reagan Revolution and Beyond, College Station: Texas A\&M University Press.

TUDDA, C. (2006) The Truth is Our Weapon, Baton Rouge: Louisiana State University Press.

VAN DIJK, T.A. (1995) Discourse Analysis as Ideology Analysis, in: Schaffner. C and Wendon, A.I. (eds) Language and Peace, Aldershot: Dartmouth Publishing. P. 17-33. 